\title{
Do Juvenile Nearctic River Otters (Lontra canadensis) Contribute to Fall Scent Marking?
}

\author{
Zach H. Olson, Sadie S. Stevens, and Thomas L. Serfass
}

Frostburg State University, Department of Biology, 101 Braddock Road, Frostburg, Maryland 21532 USA

Olson, Zach H., Sadie S. Stevens, and Thomas L. Serfass. 2005. Do juvenile Nearctic river otters (Lontra canadensis) contribute to fall scent marking? The Canadian Field-Naturalist 119(3): 457-459.

We present photographic evidence in support of the hypothesis that juvenile Nearctic River Otters (Lontra canadensis) contribute to the observed fall peak in scent marking.

Key Words: Lontra canadensis, Nearctic River Otter, scent marking, seasonal variation, Pennsylvania.

Otters scent mark by defecating, urinating, or releasing anal glandular secretions at conspicuous shoreline locations called latrine sites (Melquist and Hornocker 1983; Swimley et. al 1998). Seasonal variation in scent marking intensity has been reported for Nearctic River Otters (Lontra canadensis) with peaks in spring (March-April) and fall (September-November) in Pennsylvania (Serfass 1994; Carpenter 2001; Mills 2004). There have been many proposed explanations for seasonally variable marking intensities in otters. Seasonal variation was associated with dominance and related to the dispersal of juveniles for a population of European Otters (Lutra lutra) in Wales (Macdonald and Mason 1987). Carpenter (2001) attributed the spring peak in Pennsylvania to mate attraction during the breeding season. Similarly, Mills (2004) believed increased spring marking was related to advertisement of location and breeding condition.

Home range studies provide evidence in support of breeding advertisement and breeding-range defense as causes for a spring peak in scent marking (Melquist and Hornocker 1983; Reid et al. 1994; Spinola 2003). Spinola (2003) reported a spring increase in home range and interactions with females by male River Otters in a reintroduced population in western New York. He invoked two hypotheses to explain River Otter spacing patterns: Sandell's hypothesis (Sandell 1989 ) and the resource dispersion hypothesis (Mac-

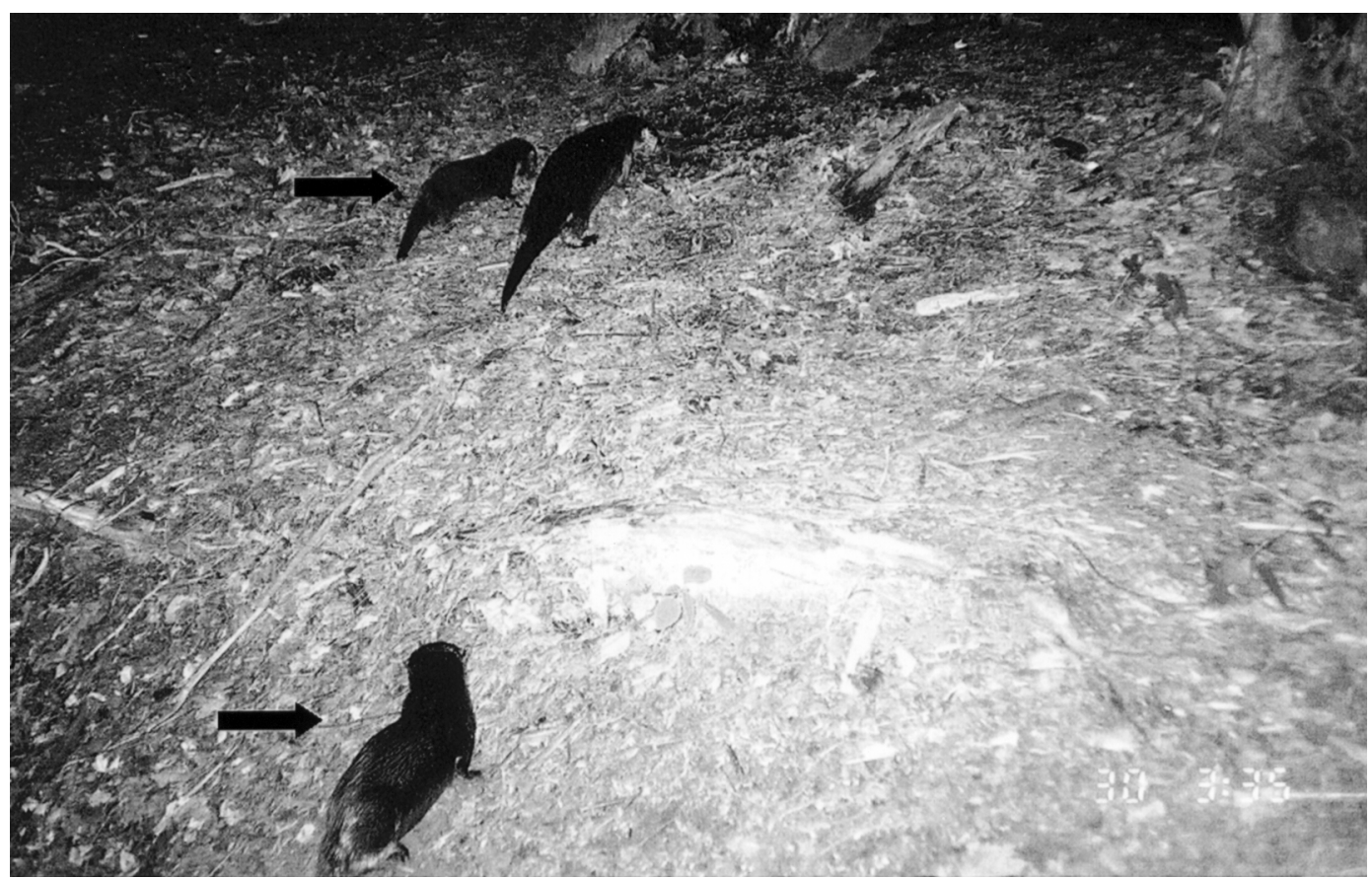

FIGURE 1. Photograph from the Youghiogheny River (Maryland) latrine site of two juvenile River Otters with one adult. The two juveniles are indicated with arrows. The juvenile in the foreground (trailing) appears large in comparison to the other River Otters because of its close proximity to the camera. The image is dated 30 June 2004. 
donald 1983; Carr and Macdonald 1986), both of which predict female intra-sexual territoriality and large male home ranges during the breeding season (Spinola 2003). Increased scent marking during this period of increased movement would likely enhance the efficiency by which males and females are able to locate one another for breeding opportunities.

Although the possible link between spring breeding advertisement and the observed spring peak in scent marking has been established, there is a paucity of literature examining causes of the fall peak in scent marking. Carpenter (2001) and Mills (2004) suggested the mechanism for a fall peak in North America was an increase in the density of marking individuals as juvenile River Otters began traveling with their mothers (juveniles were $<1$ year old). However, we are aware of no data that support this hypothesis.

As part of an ongoing behavioral study of River Otters we placed remote, $35-\mathrm{mm}$ cameras (TrailMaster®, Goodson and Associates, Inc., Lenexa, Kansas, USA) at latrine sites along Tionesta Creek in north central Pennsylvania $\left(41^{\circ} 35^{\prime} \mathrm{N}, 78^{\circ} 15^{\prime} \mathrm{W}\right)$ and the Youghiogheny River in western Maryland $\left(39^{\circ} 34^{\prime} \mathrm{N}, 79^{\circ} 25^{\prime} \mathrm{W}\right)$, United States. Two cameras captured what we presume to be two family groups (an adult female and two cubs as defined by Melquist and Hornocker 1983) of River Otters visiting latrine sites beginning 30 June 2004. We based this presumption on a size disparity apparent among individuals in three photographs containing all family group members. The photographs originated from two separate latrine sites, one from a Tionesta Creek latrine site (15 August 2004) and two from a Youghiogheny River latrine site (30 June 2004 and 31 July 2004). We continued to obtain photographs at those latrine sites ( $n=2$ at Tionesta Creek and $n=10$ at the Youghiogheny River) of what we assumed to be the same family groups through fall and winter 2004.

To estimate the lengths of the presumed juvenile and adult River Otters we took reference photographs of both latrine sites. The reference images were taken from the same camera mount and position as the original photographs and incorporated meter sticks placed at the locations of the River Otters in the original photographs. We digitally superimposed each reference image onto the original image containing the presumed family group of River Otters, thus facilitating an approximation of each individual's total length (tip of nose to tip of tail). The 30 June 2004 photograph from the Youghiogheny River was not subjected to these measurements because the size disparity was readily apparent (see Figure 1). In both of the other photographs two presumed juveniles were visible, but only one was captured completely within the photograph frame and could be measured. The presumed adult and juvenile at Tionesta Creek were $78.2 \mathrm{~cm}$ and $61.4 \mathrm{~cm}$, respectively, which yielded an adult length to juvenile length ratio of 1:0.79. At the Youghiogheny River, the presumed adult was $86.2 \mathrm{~cm}$ and the presumed juvenile was $63.8 \mathrm{~cm}$, which yielded a ratio of 1:0.74. The shorter calculated lengths than those expected from physical measurements of the same River Otters was probably due to the animated posture of the photographed individuals.

Our calculated ratios are consistent with the findings of Stephenson (1977), who reported NovemberMarch trapped $<1$ year-old River Otters in Ontario of significantly lower weight and length than all other age classes. Merriam (1884) reported observations of young otters with their mother in summer and fall in the northeastern United States. Also, Park (1971) listed fall as the season juveniles began traveling with their mothers. We propose that our photographs were of River Otter family groups, juveniles visiting latrine sites with an adult, and that the increased number of River Otters at latrine sites can explain an increase in the number of scats at latrine sites.

Liers (1951) and Melquist and Hornocker (1983) have described River Otter scent marking as a sort of positive feedback loop - one otter's scent marking induced other nearby individuals to mark, which induced another round of marking by the first otter, and so on. This type of release stimuli - possibly visual and olfactory - has been described for other scentmarking carnivores (see Beckoff 1979; Muckenhirn and Eisenberg 1972; Peters and Mech 1975; Seidensticker et al. 1973). Family groups of River Otters visiting latrine sites would, therefore, leave more scats than single otters. Although release stimuli could explain increased scat numbers at latrine sites in the fall, the function of scent marking as a group has not been addressed for River Otters. Ewer (1973) proposed that group scent marking in social carnivores could facilitate group bonding (page 250). The social significance of scent marking has been described in canids (Rothman and Mech 1979), felids (Seidensticker et al. 1973), and other mustelids (Buesching et al. 2003).

Although more information is needed before making final conclusions, we believe evidence from the literature that a family group begins to travel as a unit during summer, and our observation of juveniles accompanying an adult to latrine sites beginning in late June, lends support to the hypothesis that juvenile River Otters contribute to increased scent marking in fall. Specific aspects of River Otter scent marking at latrine sites that have not been addressed in the literature include; the composition of marking individuals, the periodicity of marking by individuals, and the relationship between functional scent marking and elimination of feces.

\section{Acknowledgments}

A United States Fish and Wildlife Service State Wildlife Grant (administered by the Pennsylvania Game Commission [PGC]), the Pennsylvania Wild Resource Conservation Fund (WRCF; nongame taxcheckoff), and the United States Department of Agriculture Allegheny National Forest (ANF) provided primary funding and support for this project. We are 
grateful to A. Hayden (deceased) and J. Hassinger of the PGC, F. Felbaum and R. Stanley of the WRCF, and B. Nelson of the ANF for their cooperation and support of River Otter research in Pennsylvania.

\section{Literature Cited}

Beckoff, M. 1979. Ground scratching by male domestic dogs: a composite signal. Journal of Mammalogy 60: 847-848.

Buesching, C. D., P. Stopka, and D. W. Macdonald. 2003. The social function of allo-marking in the European badger (Meles meles). Behaviour 140: 965-980.

Carpenter, C. P. 2001. Scat marking and use of spraint sites by river otters along Tionesta Creek, northwestern Pennsylvania. M.S. thesis, Frostburg State University, Frostburg. 95 pages.

Carr, G. M., and D. W. Macdonald. 1986. The sociality of solitary foragers: a model based on resource dispersion. Animal Behaviour 34: 1540-1549.

Ewer, R. F. 1973. The carnivores. Cornell University Press, Ithaca, New York, USA. 494 pages.

Liers, E. E. 1951. Notes on the river otter (Lutra canadensis). Journal of Mammalogy 32: 1-9.

Macdonald, D. W. 1983. The ecology of carnivore social behaviour. Nature 301: 379-384.

Macdonald, S. M., and C. F. Mason. 1987. Seasonal marking in an otter population. Acta Theriologica 32: 449-462.

Melquist, W. E., and M. G. Hornocker. 1983. Ecology of river otters in west central Idaho. Wildlife Monographs 47: $1-60$.

Merriam, C. H. 1884. The mammals of the Adirondack region, northeastern New York. L. S. Foster Press, New York, New York, USA. 316 pages.

Mills, M. A. 2004. Scat-marking by river otters in Pennsylvania and Maryland. M.S. thesis, Frostburg State University, Frostburg. 178 pages.
Muckenhirn, N. A., and J. F. Eisenberg. 1972. Home ranges and predation of the Ceylon leopard (Panthera pardus fusca). Pages 142-175 in The world's cats, volume 1. Edited by R. Eaton. World Wildlife Safari, Winston, Oregon, USA.

Park, E. 1971. The world of the otter. J. B. Lippincott Co., Philadelphia, Pennsylvania, USA. 159 pages.

Peters, R., and L. D. Mech. 1975. Scent-marking in wolves. American Scientist 63: 628-637.

Reid, D. G., S. M. Herrero, A. C. H. Reid, and T. E. Code. 1994. Spacing, movements, and habitat selection of the river otter in boreal Alberta. Canadian Journal of Zoology 72: 1314-1324.

Rothman, R. J. and L. D. Mech. 1979. Scent-marking in lone wolves and newly formed pairs. Animal Behavior 27: 750-760.

Sandell, M. 1989. The mating tactics and spacing patterns of solitary carnivores. Pages 164-182 in Carnivore behavior, ecology, and evolution. Edited by J. L. Gittleman. Cornell University Press, New York, New York, USA. 620 pages.

Seidensticker, J. C., M. G. Hornocker, W. V. Wiles, and J. P Messick. 1973. Mountain lion social organization in the Idaho Primitive Area. Wildlife Monographs 35: 1-60.

Serfass, T. L. 1994. Conservation genetics and reintroduction strategies for river otters. Ph.D. Dissertation, Pennsylvania State University, University Park. 183 pages.

Spinola, R. M. 2003. Spatio-temporal ecology of river otters translocated to western New York. Ph.D. dissertation, The Pennsylvania State University, University Park. 115 pages.

Stephenson, A. B. 1977. Age determination and morphological variation of Ontario otters. Canadian Journal of Zoology 55: 1577-1583.

Swimley, T. J., T. L. Serfass, R. P. Brooks, and W. M. Tzilkowski. 1998. Predicting river otter latrine sites in Pennsylvania. Wildlife Society Bulletin 26: 836-845.

Received 15 March 2005

Accepted 7 July 2005 